\title{
EFFECT OF FERTILIZERS SYSTEMS ON ACCUMULATION OF HEAVY METALS IN GRAY FOREST SOIL
}

\author{
Olena Litvinova ${ }^{1}$, Dmytro Litvinov $^{1 *}$, Stanislav Degodyuk ${ }^{2}$, Svitlana Romanova $^{3}$, Volodymyr Rasevich ${ }^{4}$ \\ ${ }^{1 *}$ National University of Life and Environmental Sciences of Ukraine, \\ Heroiv Oborony str., 12, bulding 7, Kyiv, 03041, Ukraine; \\ ${ }^{2} N R C$ «Institute of Agriculture NAAS», Ukraine; \\ ${ }^{3}$ State Institution «Soils Protection Institute of Ukraine», Babushkina Per., 3, Kyiv, 03190, Ukraine; \\ ${ }^{4}$ The Cherkassy state agricultural scientific research station of NRC «Institute of agriculture NAAS", Ukraine;
}

*Corresponding Author Dmytro Litvinov, e-mail address: litvinovdv2018@ukr.net;

Received July 2020; Accepted August 2020; Published September 2020;

DOI: $\underline{\text { https://doi.org/10.31407/ijees10.404 }}$

\begin{abstract}
Mobile forms content of plumbum and cadmium at systematic application of organic and mineral fertilizers in field crop rotation on gray forest soil has been investigated. It was found that the use of fertilizers affected the accumulation of these indicators in the soil relative to the initial state, but the maximum concentration of maximum permissible concentrations (MPC) was not observed. With the organic fertilizer system (60 t/ha of manure) there was a decrease in mobile plumbum by $33 \%$ compared to its initial content in the soil. However, it should be noted that the coefficient of technogenic concentration for plumbum was more than one (Kc>1), which indicates the process of its accumulation in the soil to the background level. The highest indicator of the coefficient of technogenic concentration for plumbum $(\mathrm{Kc}=2)$ was observed with the joint application of organic and mineral fertilizers (60 t/ha of manure $\left.+\mathrm{N}_{100} \mathrm{P}_{60} \mathrm{~K}_{100}\right)$. The distribution of mobile plumbum and cadmium according to the soil profile depended on the peculiarities of soil genesis - there was a tendency to increase stocks under agrochemical load in the norm $\mathrm{N}_{100} \mathrm{P}_{60} \mathrm{~K}_{100}$ against 60 t/ha of manure, in the lower part of illuvial humus and upper - illuvial horizons at a depth of 50-80 cm, as well as a decrease at the boundary of humus-eluvial and illuvial humus horizons $-25-45 \mathrm{~cm}$. Studies of the content of mobile forms of plumbum and cadmium in the grain of winter wheat indicate the stability of levels of contamination by these elements of the grain within the permissible concentrations of MPC.
\end{abstract}

Keywords: heavy metal, soil, toxic effect, plants, soil fertility, fertilizers. 